\title{
Trends in Management of Traumatic Brain Injury by Emergency Physicians in Colombia
}

Hernando Raphael Alvis-Miranda, Claudia Navas, Rosmery Villa-Delgado, Andres M Rubiano

Gabriel Alcala-Cerra, Luis Rafael Moscote-Salazar

\section{ABSTRACT}

Background: Traumatic brain injury is a common cause of death in Colombia. The aim of this study was to evaluate the management of traumatic brain injury patients in Colombia.

Materials and methods: This study was conducted through a survey sent to 100 general practitioners in Colombia through an electronic format.

Results: Over the period of the study, data collected were about 59 physicians consecutively. The $31 \%$ of the respondents knew protocols for the management of traumatic brain injury.

Conclusion: Traumatic brain injury is one of the most important reasons for consultations in the emergency services in Colombia. We observed significant differences in the initial management of patients with this kind of injury. It requires the establishment of standard protocols and transmission thereof. The implementation of these strategies will contribute to a better patient outcome in Colombia.

Keywords: Brain trauma injury, Emergency management, Craniocerebral trauma, Head injury.

How to cite this article: Alvis-Miranda HR, Navas C, VillaDelgado R, Rubiano AM, Alcala-Cerra G, Moscote-Salazar LR. Trends in Management of Traumatic Brain Injury by Emergency Physicians in Colombia. J Trauma Critical Care Emerg Surg 2013;2(3):134-138.

Source of support: Nil

Conflict of interest: None

\section{RESUMEN}

Antecedentes: La lesión cerebral traumática es una causa común de muerte en Colombia. El objetivo de este estudio fue evaluar la manejo de los pacientes con lesiones cerebrales traumáticas en Colombia.

Materiales y métodos: El estudio se realizó a través de un encuesta enviada a 100 médicos generales en Colombia a través de formato electrónico.

Resultados: Durante el período del estudio, los datos recogidos fueron aproximadamente 59 médicos consecutiva. El 31\% de los encuestados sabía protocolos para el manejo de la lesión cerebral traumática.

Conclusión: La lesión cerebral traumática es una de las más razones importantes para las consultas en los servicios de emergencia en Colombia. Se observaron diferencias significativas en la inicial manejo de los pacientes con este tipo de lesión. Se requiere que el establecimiento de protocolos y la transmisión del mismo estándar. La implementación de estas estrategias contribuirá a una mejor la evolución del paciente en Colombia.

Palabras claves: Lesión traumática del cerebro, La gestión de emergencias, Traumatismo craneoencefálico, Injur head.

\section{INTRODUCTION}

Currently morbidity and mortality due to traumatic injuries are a well-recognized major public health problem. Similarly, the traumatic brain injury (TBI) is a major public health concern worldwide, according to the predictions, neurotrauma will account an increasing number of deaths worldwide by $2020 .{ }^{1}$ Unfortunately, overall trauma ranks among the leading causes of death and occurs in all regions, affecting people in all age and income groups. ${ }^{2} \mathrm{TBI}$ is one of the most common reasons for consultation in the emergency department (ER). Trauma pathology is now a serious public health problem in the developed world, being the cause of the increased mortality from motor vehicles and the control of infectious disease.

Patients with a severe TBI can experience subsequent mental and/or medical problems. ${ }^{3,4}$ The acute consequences of TBI are just only a half of the complete problem, the long-term repercussions of TBI are substantial especially among adolescents and young adults, whose brains continue to mature and develop. ${ }^{5}$ To make matters worse, people who sustain TBI during or before adolescence can have a limited return to pretrauma academic or work activities that aggravate the economic and physical consequences derived from the treatment and the rehabilitation.

Various efforts have been made to handle the high rate of morbidity and mortality, improving prehospital care systems among others. In order to evaluate the current state of the management of TBI by general practitioners in Colombia, and offer proper statistics of care and treatment of TBI, this survey was performed.

\section{MATERIALS AND METHODS}

To determine how Colombian general practitioners evaluate and treat TBI, we developed a web-based structured survey with real time results through an online survey creator (http:// www.encuestafacil.com). The survey invitations were sent by e-mail, and aimed general practitioners who manage patients in the ER to meet its management in relation to national and international guidelines on head trauma, $6-8$ during the month of December of 2012 to march of 2013. For ethical considerations the identity of institutions surveyed was blinded. We used dichotomous choice questions, and multiple choice questions with single answer. Variables evaluated were: age, sex, topographic region of Colombia 
were the respondent resides, management of pediatric patients, and general knowledge regard TBI. Answers from the survey were compiled and entered into an Excel database (Microsoft, Redmond, Washington). Each answer to a question was placed in a corresponding category and the frequencies of each category were computed. The data were analyzed by software 17.0 (SPSS. Inc., Chicago, IL). The data obtained were analyzed statistically to determine the frequency distribution of each of the variables.

\section{RESULTS}

One-hundred and fifty general practitioners were invited to participate in the survey, of whom 59 (39.3\%) completed the survey, mainly between 20 and 34 years old, and from Caribe and Andina region, other characteristics are depicted in Table 1.

The majority of the respondents treat pediatric patients $[81.4 \%(\mathrm{n}=48)$ vs $18.6 \%(\mathrm{n}=11)]$. When asked about Glasgow Coma Scale (GCS), all respondents said that they routinely used that scale to evaluate patients with TBI. Regarding the knowledge of TBI international management guidelines or protocols, $72.9 \%$ (43) knew guidelines, while

\begin{tabular}{|c|c|c|c|}
\hline & & $\begin{array}{c}\text { Number of } \\
\text { answers }\end{array}$ & $\%$ \\
\hline \multirow[t]{4}{*}{ Gender } & Male & 28 & 47.5 \\
\hline & Female & 28 & 47.5 \\
\hline & Unanswered & 3 & 5.0 \\
\hline & Total & 59 & 100.0 \\
\hline \multirow[t]{9}{*}{ Age } & $14-19$ yrs & 0 & 0.0 \\
\hline & $20-24$ yrs & 21 & 35.6 \\
\hline & $25-34$ yrs & 32 & 54.2 \\
\hline & $35-44$ yrs & 1 & 1.7 \\
\hline & $45-54$ yrs & 2 & 3.4 \\
\hline & $55-64$ yrs & 0 & 0.0 \\
\hline & $\geq 65$ yrs & 0 & 0.0 \\
\hline & Unanswered & 3 & 5.0 \\
\hline & Total & 59 & 100.0 \\
\hline \multirow{8}{*}{$\begin{array}{l}\text { Colombian region } \\
\text { where the respondent } \\
\text { resides }\end{array}$} & Caribe & 35 & 59.3 \\
\hline & Pacifica & 1 & 1.7 \\
\hline & Andina & 19 & 32.2 \\
\hline & Insular & 0 & 0.0 \\
\hline & Orinoquia & 0 & 0.0 \\
\hline & Amazonica & 1 & 1.7 \\
\hline & Unanswered & 3 & 5.0 \\
\hline & Total & 59 & 100.0 \\
\hline
\end{tabular}

Table 2: Answers to the question of treating pediatric patients

\begin{tabular}{|l|l|l|l|}
\hline & Options & $\begin{array}{c}\text { Number of } \\
\text { answers }\end{array}$ & $\%$ \\
\hline $\begin{array}{l}\text { Do you treat pediatric } \\
\text { patients? }\end{array}$ & Yes & 48 & 81.4 \\
\hline & No & 11 & 18.6 \\
\hline & Total & 59 & 100.0 \\
\hline
\end{tabular}

$25.1 \%$ (16) did not know them. $30.5 \%$ (18) were aware of TBI management protocols in their workplace, whereas $67.8 \%$ (40) did not know of the existence of institutional protocols (Table 3).

Regarding observation times for mild TBI patients without loss of consciousness $84,7 \%$ (50) consider it adequate to observe during 0 to 6 hours, and $13.6 \%{ }^{8}$ consider to observe at least 24 hours; there was only one unanswered question. In the case of mild TBI with loss of consciousness, $71.2 \%$ (42) consider to observe for at least 24 hours, $15.3 \%{ }^{9}$ wait more than 24 hours, and $13.6 \%{ }^{8}$ consider only at least 6 hours. The other question related to observation times, was made in the context of mild TBI patient but under alcohol influence of any degree, $6.8 \%$ (4) responded that should be between 0 and 6 hours, $64.4 \%$ (38) between 6 and 24 hours and $28.8 \%$ over 24 hours (Table 4 ).

\begin{tabular}{|c|c|c|c|}
\hline & Options & $\begin{array}{c}\text { Number of } \\
\text { answers }\end{array}$ & $\%$ \\
\hline \multirow{3}{*}{$\begin{array}{l}\text { Do you routinely use } \\
\text { the Glasgow Coma } \\
\text { Scale in TBI? }\end{array}$} & Yes & 59 & 100.0 \\
\hline & No & 0 & 0.0 \\
\hline & Total & 59 & 100.0 \\
\hline \multirow{3}{*}{$\begin{array}{l}\text { Do you know TBI } \\
\text { management } \\
\text { guidelines? }\end{array}$} & Yes & 43 & 72.9 \\
\hline & No & 16 & 27.1 \\
\hline & Total & 59 & 100.0 \\
\hline \multirow{4}{*}{$\begin{array}{l}\text { In your work place, } \\
\text { do you know TBI } \\
\text { protocols? }\end{array}$} & Yes & 18 & 30.5 \\
\hline & No & 40 & 67.8 \\
\hline & Unanswered & 1 & 1.6 \\
\hline & Total & 59 & 100.0 \\
\hline
\end{tabular}

\begin{tabular}{|c|c|c|c|}
\hline & Options & $\begin{array}{c}\text { Number of } \\
\text { answers }\end{array}$ & $\%$ \\
\hline \multirow{5}{*}{$\begin{array}{l}\text { Without loss of } \\
\text { consciousness }\end{array}$} & $0-6$ hours & 50 & 84.7 \\
\hline & $6-24$ hours & 8 & 13.6 \\
\hline & $>24$ hours & 0 & 0.0 \\
\hline & Unanswered & 1 & 1.6 \\
\hline & Total & 59 & 100.0 \\
\hline \multirow{4}{*}{$\begin{array}{l}\text { With loss of } \\
\text { consciousness }\end{array}$} & $0-6$ hours & 8 & 13.6 \\
\hline & $6-24$ hours & 42 & 71.2 \\
\hline & $>24$ hours & 9 & 15.3 \\
\hline & Total & 59 & 100.0 \\
\hline \multirow{4}{*}{$\begin{array}{l}\text { In the case of patients } \\
\text { under alcohol } \\
\text { influence }\end{array}$} & $0-6$ hours & 4 & 6.8 \\
\hline & $6-24$ hours & 38 & 64.4 \\
\hline & $>24$ hours & 17 & 28.8 \\
\hline & Total & 59 & 100.0 \\
\hline
\end{tabular}


About fluid therapy preferences (Table 5), the main type was crystalloids $(83.1 \% ; \mathrm{n}=49)$, others consider colloids $(6.95 ; \mathrm{n}=4)$, and $5(8.5 \%)$ respondents were indifferent to the type of fluid solution. More specifically, mannitol was considered mainly for severe TBI $(52.5 \% ; \mathrm{n}=31) .20 .3 \%$ $(n=12)$ considered its use in severe and moderate TBI, $6.8 \%$ $(\mathrm{n}=4)$ considered its use only in moderate TBI, and $20.3 \%$ $(\mathrm{n}=12)$ never considered its use. The other specific fluid asked was hypertonic saline, its use was considered mainly for severe TBI $(37.3 \% ; n=22), 23.7 \%(n=14)$ considered it in severe and moderate TBI; $5.1 \%(\mathrm{n}=3)$ considered its use only in moderate TBI; $27.1 \%(n=16)$ never considered its use and $6.8 \%(n=4)$ always considered its use.

Other concern for evaluation was the consideration of key indications for taking critical decisions such as imaging and referral to higher level of medical attention (Table 6). In the questions about indications for the performing of brain CT-scan in TBI from a list options, $6.8 \%$ (4) would do it for any neurological impairment, $18.6 \%$ (11) neurological impairment and vomiting, 32.2\% (19) vomiting, abnormal neurological status and others; $27.1 \%$ (16) selected neurological alteration and any other alteration, and $13.6 \%$ (8) always. When inquiring about what criteria were required in a head injured patient to be referred to a higher level of care, $6.8 \%$ (4) answered that any neurological alteration, $5.1 \%$ (3) the lack of neuroimaging and/or unavailability

\begin{tabular}{|c|c|c|c|}
\hline \multicolumn{4}{|c|}{ Table 5: Fluid therapy in TBI } \\
\hline & Options & $\begin{array}{c}\text { Number of } \\
\text { answers }\end{array}$ & $\%$ \\
\hline \multirow[t]{6}{*}{ Mannitol use in TBI } & Severe TBI & 31 & 52.5 \\
\hline & $\begin{array}{l}\text { Moderate } \\
\text { TBI }\end{array}$ & 4 & 6.8 \\
\hline & $\begin{array}{l}\text { Severe and } \\
\text { moderate } \\
\text { TBI }\end{array}$ & 12 & 20.3 \\
\hline & Never & 12 & 20.3 \\
\hline & Always & 0 & 0.0 \\
\hline & Total & 59 & 100.0 \\
\hline \multirow{6}{*}{$\begin{array}{l}\text { Hypertonic saline in } \\
\text { TBI }\end{array}$} & Severe TBI & 22 & 37.3 \\
\hline & $\begin{array}{l}\text { Moderate } \\
\text { TBI }\end{array}$ & 3 & 5.1 \\
\hline & $\begin{array}{l}\text { Severe and } \\
\text { moderate } \\
\text { TBI }\end{array}$ & 14 & 23.7 \\
\hline & Never & 16 & 27.1 \\
\hline & Always & 4 & 6.8 \\
\hline & Total & 59 & 100.0 \\
\hline \multirow{5}{*}{$\begin{array}{l}\text { Type of intravenous } \\
\text { fluid preference }\end{array}$} & Colloyd's & 4 & 6.8 \\
\hline & Crystalloids & 49 & 83.1 \\
\hline & Indifferent & 5 & 8.5 \\
\hline & Unanswered & 1 & 1.6 \\
\hline & Total & 59 & 100.0 \\
\hline
\end{tabular}

of specialists and $86.4 \%$ (51) responded that any TBI with neurological impairment, with or without politrauma, or the unavailability of neuroimaging and specialists require referral.

In the information of recommendations to patients and their families about when to return to ER, 96.6\% (56) routinely do it, and 3.4\% (2) do not (Table 7).

\section{DISCUSSION}

The traumatic brain injury (TBI) is defined as an injury to the head arising from blunt or penetrating trauma or from

\begin{tabular}{|c|c|c|c|}
\hline & Options & $\begin{array}{l}\text { Number of } \\
\text { answers }\end{array}$ & $\%$ \\
\hline \multirow[t]{9}{*}{$\begin{array}{l}\text { Brain CT-scan in } \\
\text { TBI }\end{array}$} & $\begin{array}{l}\text { Neurological } \\
\text { impairment }\end{array}$ & 4 & 6.8 \\
\hline & $\begin{array}{l}\text { Vomit and } \\
\text { neurological } \\
\text { impairment }\end{array}$ & 11 & 18.6 \\
\hline & $\begin{array}{l}\text { Vomit, } \\
\text { neurological } \\
\text { impairment and } \\
\text { others }\end{array}$ & 19 & 32.2 \\
\hline & $\begin{array}{l}\text { Persistent } \\
\text { vomiting }\end{array}$ & 0 & 0.0 \\
\hline & $\begin{array}{l}\text { Vomit and } \\
\text { others }\end{array}$ & 1 & 1.7 \\
\hline & $\begin{array}{l}\text { Neurological } \\
\text { impairment and } \\
\text { others }\end{array}$ & 16 & 27.1 \\
\hline & Always & 8 & 13.6 \\
\hline & Never & 0 & 0.0 \\
\hline & Total & 59 & 100.0 \\
\hline \multirow{7}{*}{$\begin{array}{l}\text { Conditions } \\
\text { considered to refer } \\
\text { a TBI patient to } \\
\text { a higher level of } \\
\text { attention }\end{array}$} & $\begin{array}{l}\text { Neurological } \\
\text { impairment }\end{array}$ & 4 & 6.8 \\
\hline & Polytrauma & 0 & 0.0 \\
\hline & $\begin{array}{l}\text { Unavailability of } \\
\text { neuroimaging or } \\
\text { specialist }\end{array}$ & 3 & 5.1 \\
\hline & All & 51 & 86.4 \\
\hline & None & 0 & 0.0 \\
\hline & Unanswered & 1 & 1.6 \\
\hline & Total & 59 & 100.0 \\
\hline
\end{tabular}

Table 7: Answers to the question: Do you routinely inform recommendations about when to return to $E R$ in a patient with mild TBI?

\begin{tabular}{|l|l|l|l|}
\hline & \multicolumn{1}{|c|}{ Options } & $\begin{array}{c}\text { Number of } \\
\text { answers }\end{array}$ & $\%$ \\
\hline $\begin{array}{l}\text { Inform } \\
\text { recommendations } \\
\text { about when to } \\
\text { return to ER }\end{array}$ & Yes & 56 & 94.9 \\
\hline \multirow{1}{*}{} & No & 2 & 3.4 \\
\hline & Unanswered & 1 & 1.6 \\
\hline & Total & 59 & 100.0 \\
\hline
\end{tabular}


acceleration/deceleration forces associated with one or more of the following: decreased level of consciousness, amnesia, objective neurologic or neuropsychological abnormality(ies), skull fracture(s), diagnosed intracranial lesion(s), or head injury listed as a cause of death in the death certificate. ${ }^{9,10}$ TBI is a major public health concern worldwide. ${ }^{1}$ It ranks among the leading causes of death and occurs in all regions, affecting people in all age and income groups. ${ }^{2}$ More clearly, TBI is the most common cause of death and disability in children and young adults. ${ }^{11}$ In the United States (USA), TBI generate 235.000 hospitalizations, 50000 deaths, and permanent disability in $99000 .{ }^{26}$ It course with a high economic burden, only in the USA in 2000 was estimated in $\$ 110$ billion derived from direct (e.g. medical) and indirect (e.g. lost productivity) costs. ${ }^{12}$

All assessment, diagnostic and therapeutic tools have its own indications, and exist protocols for the management of TBI in ER regardless the place. This brain injury is characterized by the fact that patients without a severe TBI, can experience subsequent mental and/or medical problems. ${ }^{3,4}$ And due to the fact that general physician, specifically in Colombia, is one of the first trauma team members to have contact with the TBI patient, it is necessary that this health professional be capable to receive, assess, make clinical impressions, differential diagnosis, and start a good evidence-based treatment therapy, as offered by the current TBI guidelines. Indisputably a critical factor for the prognosis and outcome of TBI patients also rests in the medical skills, academic preparation, and experience of the healthcare members who attend them. Unfortunately the acute consequences of TBI are just only a half of the complete problem, the long-term repercussions of TBI are substantial especially among adolescents and young adults, whose brains continue to mature and develop. ${ }^{5}$ While there are pathophysiological aspects that can be unchangeable, a fast and high quality medical attention, gives the trauma group the incisive opportunity to impact positively on this aspect. Especially attacking and recognizing potential complications, the occurrence of secondary lesions, because appropriate measures taken during initial ER management and subsequently in the ICU can significantly improve outcome. ${ }^{13}$ The primary goal is to limit secondary brain injury. Early imaging, rather than admission and observation for neurological deterioration, reduces the time to the detection of life-threatening complications. ${ }^{13}$

Recognizing that our health systems have failures seemingly insignificant, are a priority issue for improving, for example in a recent study aiming to investigate the extent to which the documentation of key indicators of healthcare quality in the ED setting was consistent with clinical guidelines for the management of children with mild
TBI, was observed that the apparent absence of a systematic approach to the diagnosis and follow-up of mild TBI in children presenting to ED suggests a missed opportunity to minimize the risk of disability following these injuries. ${ }^{14}$ The conclusion of the study is that greater attention to an integrated care pathway that improves the identification, documentation, and follow-up of children with MTBI presenting to ED is required. ${ }^{14}$

There is also others controversies, for example, it exists a significant variation in perceptions of neurological prognosis and in clinical decision making on the level of care even among intensivists, neurosurgeons and neurologists, ${ }^{15}$ when assessing mortality following the withdrawal of life-sustaining therapies, that in turn is high and variable across centers.

Analysis of TBI in prehospital and in the emergency departments in Poland had find as neuralgic points to standardize the emergency medical records and initial emergency procedures, to organize multitrauma teams, and to decrease the time of the referral process and the definitive care. ${ }^{16}$

In conclusion, it is important that the emergency care physician, who first receives the TBI patient, has solid concepts when assessing, diagnosing and treating these patients and to prevent secondary brain injury. The present survey should serve as a framework for creating a continuing medical education course to enhance the knowledge and practice of the initial management of TBI.

\section{CONCLUSION}

Although web-based surveys do not represent the general population of general practitioners in our country, this kind of survey reaches people who have access to internet or have an email, in the same fashion as telephone surveys only reach people who have telephone. This survey, however simplistic, has a relevant conclusion that it is necessary to improve state policies to disseminate international management guidelines among general practitioners in Colombia. Such implementation of guidelines and protocols will allow a homogeneous management through the entire country and may contribute to better outcomes for our patients.

\section{REFERENCES}

1. Murray CJ, Lopez AD. Alternative projections of mortality and disability by cause 1990-2020: Global Burden of Disease Study. Lancet 1997;349:1498-1504.

2. Hyder AA, Aggarwal A. The increasing burden of injuries in Eastern Europe and Eurasia: making the case for safety investments. Health Policy 2009;89:1-13.

3. Galarneau MR, Woodruff SI, Dye JL, Mohrle CR, Wade AL. Traumatic brain injury during Operation Iraqi Freedom: findings from the United States Navy-Marine Corps Combat Trauma Registry. J Neurosurg 2008;108:950-957. 
4. Okie S. Traumatic brain injury in the war zone. N Engl J Med 2005;352:2043-2047.

5. Pujol J, Vendrell P, Junqué C, Martí-Vilalta JL, Capdevila A. When does human brain development end? Evidence of corpus callosum growth up to adulthood. Ann Neurol 1993;34:71-75.

6. Sabogal Barrios R, Moscote Salazar LR. Neurotrauma: Fundamentos para un manejo Integral (E-Book) 2007. Cartagena de Indias, 55-75.

7. Guidelines for the management of severe traumatic brain injury. Journal of Neurotrauma 2007;24 Suppl 1:S1-106.

8. Bullock MR, Chesnut R, Ghajar J, Gordon D, Hartl R, Newell DW, Servadei F, Walters BC, Wilberger JE. Guidelines for the Surgical Management of Traumatic Brain Injury. Neurosurgery 2006;58:S2-1-S2-3.

9. Coronado VG, McGuire LC, Sarmiento K, Bell J, Lionbarger MR, Jones CD, Geller AI, Khoury N, Xu L. Trends in traumatic brain injury in the US and the public health response: 1995-2009. J Safety Res 2012;43:299-307.

10. Traumatic Brain Injury in the United States: A Report to Congress. Atlanta, GA: Centers for Disease Control and Prevention, 1999:2.

11. Goodman MD, Makley AT, Lentsch AB, Barnes SL, Dorlac GR, Dorlac WC, Johannigman JA, Pritts TA. Traumatic brain injury and aeromedical evacuation: when is the brain fit to fly? J Surg Res 2010;164:286-293.

12. Graves JM, Sears JM, Vavilala MS, Rivara FP. The burden of traumatic brain injury among adolescent and young adult workers in Washington State. Journal of Safety Research 2013 June;45:133-139.

13. Mittal R, Vermani E, Tweedie I, Nee PA. Critical care in the emergency department: traumatic brain injury. Emerg Med J 2009;26:513-517.

14. Sharpe S, Kool B, Shepherd M, Dalziel S, Ameratunga S. Mild traumatic brain injury: improving quality of care in the paediatric emergency department setting. J Paediatr Child Health 2012;48:170-176.
15. Turgeon AF, Lauzier F, Burns KEA, Meade MO, Scales DC, Zarychanski R, Moore L, Zygun DA, McIntyre LA, Kanji S, et al. Determination of neurological prognosis and clinical decision making in adult patients with severe traumatic brain injury: A Survey of Canadian Intensivists, Neurosurgeons and Neurologists. Crit Care Med 2013 Apr;41(4):1086-1093.

16. Zabek M, Zaczyński A. The golden hour and the dull reality. Analysis of traumatic brain injury management in prehospital and emergency care. Neurol Neurochir Pol 2007;41:22-27.

\section{ABOUT THE AUTHORS}

\section{Hernando Raphael Alvis-Miranda}

Physician, Universidad de Cartagena, Cartagena, Colombia

\section{Claudia Navas}

Physician, Universidad Industrial de Santander, Bucaramanga Colombia

\section{Rosmery Villa-Delgado}

Physician, Universidad de Cartagena, Cartagena, Colombia

\section{Andres M Rubiano}

Neurosurgeon, Fundacion Meditech, Hospital Universitario de Neiva Colombia

\section{Gabriel Alcala-Cerra}

Resident, Department of Neurosurgery, Universidad de Cartagena Cartagena, Colombia

\section{Luis Rafael Moscote-Salazar (Corresponding Author)}

Neurosurgeon, Universidad de Cartagena, Cartagena, Colombia e-mail: mineurocirujano@aol.com 